\title{
Effects of Mango Wastes-Based Diets on the Growing Parameters of Laying Hens and Biometric Parameters of the Eggs
}

\author{
Drissa Barry ${ }^{1}$, Timbilfou Kiendrebeogo ${ }^{1 *}$, Modou Sere ${ }^{2}$, Alima Combari ${ }^{1}$, \\ Youssouf Mopaté Logténé ${ }^{3,4}$, Chantal Yvette Kaboré-Zoungrana ${ }^{4}$ \\ ${ }^{1}$ Institut de l'Environnement et de Recherches Agricoles (INERA), Station de Farako-ba, Bobo-Dioulasso, Burkina Faso \\ ${ }^{2}$ Université de Dédougou (UD), Dédougou, Burkina Faso \\ ${ }^{3}$ Institut de Recherches en Elevage pour le Développement (IRED), N’Djamena, Chad \\ ${ }^{4}$ Laboratoire d'Etudes et de Recherches sur les Ressources Naturelles et des Sciences de l'Environnement (LERNSE), \\ Université Nazi Boni, Bobo-Dioulasso, Burkina Faso \\ Email: *timbilfou@gmail.com
}

How to cite this paper: Barry, D., Kiendrebeogo, T., Sere, M., Combari, A., Logténé, Y.M. and Kaboré-Zoungrana, C.Y. (2019) Effects of Mango Wastes-Based Diets on the Growing Parameters of Laying Hens and Biometric Parameters of the Eggs. Open Access Library Journal, 6: e5868.

https://doi.org/10.4236/oalib.1105868

Received: October 17, 2019

Accepted: November 4, 2019

Published: November 7, 2019

Copyright $\odot 2019$ by author(s) and Open Access Library Inc.

This work is licensed under the Creative Commons Attribution International License (CC BY 4.0).

http://creativecommons.org/licenses/by/4.0/

\begin{abstract}
Introduction: Poultry production has increased during the past half century throughout the world. In Burkina Faso modern poultry farming is becoming a necessity in view of the growing demand for eggs. Intensive poultry farming is developing rapidly, given that the productivity of local poultry remains very low Because of the low availability and high cost of food. Therefore, it becomes imperative to develop strategies to make modern poultry farming more productive, by finding alternative solutions for feeds. Objective: The study aims to evaluate the effects of diets incorporating mango waste-based feed on the growth parameters of laying hens and biometric parameters of first eggs. Methods: Two hundred and ten (10) hens of the Isa Brown breed were divided into 3 batches (70 chicks per set) and feed with three diets namely mango and maize diet $(\mathrm{MMD}=$ lot1), control maize diet $(\mathrm{CMD}=\operatorname{lot} 2)$ and absolute control diet $(\mathrm{ACD}=\operatorname{lot} 3)$ in a feed experiment at INERA research station in Farako-bâ, Bobo Dioulasso. Results: The final average weight (FW) gained by the lot 1 and lot3 using the diet CMD $(1364 \pm 114 \mathrm{~g})$ and ACD $(1364 \pm 115 \mathrm{~g})$, respectively was significantly higher than the lot 2 feed with the MMD diet $(1265 \pm 117 \mathrm{~g})(\mathrm{p}<0.05)$. The average daily weight gain $(\mathrm{ADG})$ of CMD and ACD was significantly $(\mathrm{p}<0.05)$ higher than that of the MMD ration. The feed intake (FI) and consumption index (CI) of the MMD ration were significantly $(\mathrm{p}<0.05)$ higher than those of CMD and ACD $(\mathrm{p}>0.05)$. Average weight and egg density were similar $(p>0.05)$ for the three diets. The eggs on the MMD diet were larger $(\mathrm{p}<0.05)$ than those in the ration's
\end{abstract}


$\mathrm{CMD}$ and $\mathrm{ACD}$, but the two later were similar ( $\mathrm{p}>0.05)$. Conclusion: Maize can be substituted with mango feed in growing layer diets. Mango waste-based feed is predisposed for better preparation of growing layers for good laying performances. It is an alternative to increase the availability of feed for farm animals including the laying hen.

\section{Subject Areas}

Agricultural Science, Food Science \& Technology, Microbiology

\section{Keywords}

Mango Waste Diets, Layers Hens, Growth Performance,

Eggs Biometric Parameters

\section{Introduction}

Poultry production has increased during the past half century throughout the world. It is estimated that during the 1990s the world's poultry population grew by $23 \%$ in developed countries and $76 \%$ in developing countries. Eggs consumption has probably become the most important source of quality animal protein available in the Burkinabe market [1]. In fact, egg is the cheapest source of proteins and animal lipids, consumed worldwide, because of its remarkable amino acid composition that almost perfectly responds to human beings needs [2], although it has long been considered as a reference proteins source, egg is a perfect food for people in developing countries [3]. It ensures $20 \%$ to $30 \%$ of the human's daily values in numerous vitamins and minerals [1]. Egg is the perfect indicated food for populations in developing countries. In Burkina Faso, modern poultry farming, which was once seen as a luxury production, is becoming a necessity in view of the growing demand for eggs by the population. The production of guinea fowl eggs once popular with the rural and urban population remains insufficient and seasonal. Intensive poultry farming is developing rapidly, given that the productivity of local poultry remains very low [4] [5]. Therefore, it becomes imperative to develop strategies to make modern poultry farming more productive in Burkina Faso, by finding alternative solutions for feeds, which is the major constraint of this sector [6] [7]. The main sources of energy which are maize, sorghum and millet, are under heavy pressure because of their uses for human consumption [8]. This situation led many poor breeders to avoid or even to use in a very low quantity these feeds essential to the growth and the quick fattening of the chickens. In order to find solutions to this constraint, research on unconventional feeds was conducted [8] [9]. It is in this dynamic that a process of the production of pig feeds based on mango waste has been developed by [9]. Based on this process, feeds were produced in 2015 and 2016 for utilization in various feeding tests on pigs, sheep and poultry. The aim of this study is to evaluate the effects of a diet based on mango wastes on the growth of laying hens as 
well as on the biometric parameters of the first eggs laid.

\section{Material and Methods}

\subsection{Study Area}

The study was conducted at the Research Station of Farako-bâ, of the Institute of Environment and Agricultural Research (INERA). It is located at $15 \mathrm{~km}$ in the south of Bobo-Dioulasso, on the road of Bobo-Dioulasso-Banfora. Its geographical coordinates are at $04^{\circ} 20^{\prime}$ longitude West and at latitude $11^{\circ} 06^{\prime}$ North. The station of Farako-bâ is located in the south-Sudanian climate zone between the 1000 and $1200 \mathrm{~mm}$ of isohyets [10]. Two seasons alternate: a rainy season of 6 months (May to October) and a dry season of 6 months (November to April). The highest temperatures were recorded in April $\left(31.04^{\circ} \mathrm{C}\right)$ and May $\left(32.0^{\circ} \mathrm{C}\right)$ and the lowest averages in January $\left(21.5^{\circ} \mathrm{C}\right)$ and December $\left(23.5^{\circ} \mathrm{C}\right)$, according to meteorological data from Farako-bâ station in 2015.

\subsection{The Hen's Habitat}

It is a semi-opened building with natural ventilation built in blocks in a North-South orientation. It is capped with a roof, by a single slope facing the East, with an overflow of $1.50 \mathrm{~cm}$ constituting a lampshade. It is compartmentalized in 6 boxes with an area of $5.95 \mathrm{~m}^{2}$ each, that is to say $3.5 \mathrm{~m} \times 1.7 \mathrm{~m}$. Rice balls were used for litter which was renewed every two weeks. An electric heating device made of 2 bulbs of 100 Watts each per box has been installed in the habitat to ensure the heating for chicks, especially during periods of low temperature. The habitat was disinfected with sodium hypochlorite (bleach), virunet ${ }^{\circledR}$ and quicklime before the subjects were introduced.

\subsection{The Animals}

The animal material was constituted of 210 growing layers of eleven (11) weeks old. They were taken from a group of 2000 growing layers reared at the FarakoBâ Station. These growing layers are of the ISA-Brown red color origin. They were identified with a loop each attached to the left wing. They were then divided into 3 batches of average weight significantly homogeneous $(p>0.05)$ of 70 growing layer each. Each lot is divided into 2 sub-lots of 35 growing layers each to reduce competition between for feed. After their placement in the boxes, an anti-stress, an anti-infectives incorporating a vitamin antibiotic and an anticoccidial as a preventive cover were administered in the drinking water

\subsection{Feed Diets Tested}

Three rations were used: an experimental ration containing mango waste called mango and maize ration (MMD), a maize control ration (CMD) formulated according to the recommendations and an absolute control ration (ACD) which is the one given to growing layers reared by the production unit of the Farako-ba station where the growing layers were taken, were served respectively to the 
batches 1,2 and 3. The centesimal compositions of MMD and CMD and their nutrient offer were calculated and recorded in Table 1. The percentage composition of ACD was not determined. It was simply taken from the feed prepared by the Station for the Basic breeding where the growing layers were taken. The three rations were analyzed at the Chemical Laboratory of Senegalese Institut of Agricultural Researches (ISRA) at Dakar to determine their chemical composition (Table 2). Two stages were observed during the feed distribution: a growth period of growing layers (11 - 18 weeks) and a spawning period (18- 24 weeks). The rations were distributed on the basis of theoretical calculations due to the late availability of laboratory results.

\subsection{Zootechnic and Production Parameters}

The following data were collected during 15 weeks experimentation. During 8 weeks, weekly weighing of the chickens, as well as daily weighing of the food refusal before the distribution of morning food, made it possible to calculate the average daily gain (ADG), the feed intake (FI) and the index of consumption (CI), as done by [11]. A weekly weighing during 8 weeks of the growing layers for the growth parameters valuation was carried out:

Feed intake calculated from the following formula: $F I(\mathrm{~g})=(Q F D-F R)$; with $Q F D=$ quantity of food distributed per day and $F R=$ Food refusal;

The average daily gain calculated from the life weights $(L W)$ obtained from the weighing during the growth period by the formula:

$$
A D G(g)=(L W j-L W i) / \text { number of days between dates } i \text { and } j \text {; }
$$

The consumption index is the ratio between the weight of the food consumed and the weight gained of the growing layers: $C I=F I(\mathrm{~g}) / A D G(\mathrm{~g})$.

During the first month of the laying phase, the eggs were collected each morning

Table 1. Centesimal composition of rations tested.

\begin{tabular}{|c|c|c|c|c|c|c|}
\hline \multirow{2}{*}{ Ingredients } & \multicolumn{3}{|c|}{ Growth phase (11 - 18 weeks) } & \multicolumn{3}{|c|}{ Spawning phase (18 - 24 weeks) } \\
\hline & MMD & CMD & $\mathrm{ACD}$ & MMD & CMD & $\mathrm{ACD}$ \\
\hline Provende of mango & 55 & - & - & 56.3 & - & - \\
\hline Maize & 18 & 69 & - & 18 & 70.2 & - \\
\hline Corn bran & - & 9.75 & - & - & 9.75 & - \\
\hline Soybean meal & 15.35 & 11.7 & - & 15.35 & 11.7 & - \\
\hline Oyster shells & 1 & 1 & - & 1 & 1 & - \\
\hline Fish meal & 5 & 3 & - & 5 & 3 & - \\
\hline Vegetal oil & 3 & 2.9 & - & 1.7 & 2.9 & - \\
\hline Salt & 0.3 & 0.3 & - & 0.3 & 0.3 & - \\
\hline Methionine & 0.3 & 0.3 & - & 0.3 & 0.3 & - \\
\hline Lysine & 0.3 & 0.3 & - & 0.3 & 0.3 & - \\
\hline CMV & 1.75 & 1.75 & - & 1.75 & 1.75 & - \\
\hline
\end{tabular}

$\mathrm{MMD}=$ Mango maize diet $\mathrm{CMD}=$ Control maize diet $\mathrm{ACD}=$ Absolute control diet . 
Table 2. Nutritional and energy contribution of the rations.

\begin{tabular}{|c|c|c|c|c|c|c|}
\hline \multicolumn{7}{|c|}{ Nutritional and energy contribution of rations (theoretical calculation result) } \\
\hline \multirow{2}{*}{ Ingredients } & \multicolumn{3}{|c|}{ Chick phase (11 - 18 weeks) } & \multicolumn{3}{|c|}{ Spawning phase (18 - 24 weeks) } \\
\hline & MMD & CMD & $\mathrm{ACD}$ & MMD & $\mathrm{CMD}$ & $\mathrm{ACD}$ \\
\hline MS (\%) & 94.87 & 95.02 & - & 94.88 & 94.8 & - \\
\hline $\mathrm{EM}(\mathrm{Kcal} / \mathrm{kg})$ & 2724.239 & 2717.0475 & - & 2786.67 & 2786.15 & - \\
\hline Crude protein (\%) & 16.14 & 16.02 & - & 16.25 & 16.14 & - \\
\hline Lysine (\%) & 0.48 & 0.57 & - & 0.48 & 0.57 & - \\
\hline Methionine (\%) & 0.48 & 0.57 & - & 0.48 & 0.57 & - \\
\hline Fat (\%) & 2.41 & 1.69 & - & 1.99 & 1.29 & - \\
\hline Phosphorus. (\%) & 0.39 & 0.39 & - & 0.4 & 0.39 & - \\
\hline Crude fiber (\%) & 13.75 & 9.18 & - & 14.02 & 9.3 & - \\
\hline Cost (FCFA/kg MS) & 235.15 & 218.86 & - & 218.86 & 209.86 & - \\
\hline \multicolumn{7}{|c|}{ Nutritional and energy contribution of rations (Analyze result) } \\
\hline MS (\%) & 91.41 & 89.49 & 89.34 & & & 89.34 \\
\hline $\mathrm{EM}(\mathrm{Kcal} / \mathrm{Kg}$ de MS) & 2000 & 3618 & 3384 & & & 3384 \\
\hline Crude protein $(\%)$ & 17.48 & 19.41 & 19.32 & & & 19.32 \\
\hline Lysine (\%) & - & - & - & & & - \\
\hline Methionine (\%) & - & - & - & & & - \\
\hline Calcium & 1.16 & 0.74 & 1.68 & & & 1.68 \\
\hline Phosphorus & 0.59 & 0.41 & 0.44 & & & 0.44 \\
\hline Crude fiber & 25.52 & 7.44 & 5.67 & & & 5.67 \\
\hline MG & 8.04 & 6.55 & 5.61 & & & 5.61 \\
\hline $\mathrm{NDF}$ & 63.02 & 71.6 & 63.08 & & & 63.08 \\
\hline $\mathrm{ADF}$ & 31.63 & 11.51 & 12.23 & & & 12.23 \\
\hline Lignin & 10.28 & 3.55 & 2.66 & & & 2.66 \\
\hline
\end{tabular}

$\mathrm{MMD}=$ Mango maize diet $\mathrm{CMD}=$ Control maize diet $\mathrm{ACD}=$ Absolute control diet.

and weighed one by one for the follow-up of the laying parameters: the number of eggs per ration, the weight of the eggs, the length (large diameter) and width (small diameter) of the eggs the large diameter and the small one was measured using a calliper. This phase has covered lasted 4 weeks. The following parameters of the egg were either directly obtained for the number of eggs laid per batch, per collection and counting, or calculated for:

The average weight of eggs per batch, per weighing after collection;

The length and width of the eggs by direct measurements with a caliper;

The egg volume was calculated according to the following formula: $V\left(\mathrm{~cm}^{3}\right)=0.476 \times D(\mathrm{~cm}) \times d^{2}\left(\mathrm{~cm}^{2}\right) / 1000$ where $D$ and $d$ are respectively large and small diameter [12].

The density of the eggs: according to the rations is calculated through the 
formula $D\left(\mathrm{~g} / \mathrm{cm}^{3}\right)=P / V$ where $P$ is egg weight and $V$ its volume [13].

The shape index of the eggs of each diet is calculated through the formula $I F=(d \times D) / 100$ where $d$ and $D$ are the length and the width of the egg measured in $\mathrm{mm}[14]$.

\subsection{Statistical Analyzes}

The data were recorded in the software Microsoft Excel 2013 then analyzed thanks to the software XLSTAT Version 2014 software. Some variance Analyzes (ANOVA) using Fisher model (LSD) $(\mathrm{p}<0.05)$ were made for averages comparison of the diets of some studied parameters (Pellet Weight, ADG, FI, CI, egg weight, volume and density). The laying rates for each week were also calculated.

\section{Results}

\subsection{Growing Layer Growth Parameters}

The growth was current in all the diets during the first stage of the test. The average initial weights (IW) were significantly homogeneous $(\mathrm{p}>0.05)$ for all diets (Table 3). The final average weight (FW) of the MMD diet was significantly lower than that of the CMD and ACD diets, which were homogeneous $(p>0.05)$ between them.

\subsection{Influence of Diets on Growing Layer Growth}

The ADGs (Table 4) were significantly homogeneous between CMD and ACD diets ( $\mathrm{p}>0.05)$. The ADG of MMD was lower than that of CMD and ACD ( $\mathrm{p}<$ $0.05)$. On the opposite, the self-willed food intake (FI) and the consumption index $(\mathrm{CI})$ of the MMD diet were significantly $(\mathrm{p}<0.05)$ higher than those of the

Table 3. Initial weights (PI) and final weights (PF) of growing layer.

\begin{tabular}{ccccccc}
\hline \multirow{2}{*}{ Rations } & \multicolumn{3}{c}{ Initial weights } & \multicolumn{3}{c}{ Final weights } \\
\cline { 2 - 6 } & $\mathbf{N}$ & Mean & Standard deviation & $\mathbf{N}$ & Mean & Standard deviation \\
\hline MMD & 70 & $894.86^{\mathrm{a}}$ & 100.855 & 70 & $1265.06^{\mathrm{a}}$ & 116.524 \\
CMD & 70 & $906.09^{\mathrm{a}}$ & 75.28 & 70 & $1364.37^{\mathrm{b}}$ & 114.35 \\
ACD & 70 & $896.01^{\mathrm{a}}$ & 86.085 & 69 & $1364.22^{\mathrm{b}}$ & 115.178 \\
\hline
\end{tabular}

$\mathrm{MMD}=$ Mango maize diet; $\mathrm{CMD}=$ Control maize diet $\mathrm{ACD}=$ Absolute control diet.

Table 4. Daily Average Gain (DAG), Voluntary Consumption (VC) and Consumption Index.

\begin{tabular}{|c|c|c|c|c|}
\hline \multirow{2}{*}{ Rations } & \multicolumn{4}{|c|}{ Parameters } \\
\hline & $\mathbf{N}$ & $\mathrm{ADG}(\mathrm{g})$ & FI (g) & $\mathrm{CI}$ \\
\hline MMD & 70 & $9.18 \pm 1.63^{\mathrm{a}}$ & $66.48 \pm 4.71^{\mathrm{a}}$ & $7.25 \pm 0.15^{\mathrm{a}}$ \\
\hline CMD & 70 & $10.95 \pm 1.60^{\mathrm{b}}$ & $60.73 \pm 4.88^{\mathrm{b}}$ & $5.55 \pm 0.45^{\mathrm{b}}$ \\
\hline $\mathrm{ACD}$ & 70 & $10.59 \pm 3.31^{\mathrm{b}}$ & $60.90 \pm 4.22^{\mathrm{b}}$ & $5.75 \pm 0.40^{\mathrm{b}}$ \\
\hline
\end{tabular}

$\mathrm{MMD}=$ Mango maize diet $\mathrm{CMD}=$ Control maize diet $\mathrm{ACD}=$ Absolute control diet. 
CMD and ACD diets. The absolute values of the $\mathrm{CI}$ and FI of the ACD diet were higher than those of the CMD diet. The ADG of this latter diet was higher than that of ACD.

\subsection{Evolution of the Number of the Eggs Laid during the First Month}

During the first month of laying, the hens laid 774 eggs in total with respectively 134 eggs (17\% of the eggs laid) for MMD, 283 eggs (36.56\%) for ACD and 357 eggs (49.48\%) CMD. The chicken feed with diets CMD and ACD started laying in the $18^{\text {th }}$ week. Those using the MMD started their laying in the $19^{\text {th }}$ week. The laying rates were regularly increasing for those using $\mathrm{CMD}$ and $\mathrm{ACD}$. For the ration MMD, there was an upwards peak in the $2^{\text {nd }}$ week. The average laying rates in the $1^{\text {st }}$ and in the $4^{\text {th }}$ weeks were homogenous between CMD and ACD $(p=0.000)$ and higher than the one of MMD $(p=0.000)$. During the $2^{\text {nd }}$ week, the homogenous laying rates of MMD and ACD were significantly lower than the one of CMD $(\mathrm{p}=0.000)$. In the $3^{\text {rd }}$ week, the rates of CMD and ACD were higher than the MMD one $(\mathrm{p}=0.000)$.

\subsection{Evolution of the Weight of the Laid Eggs during the First Month of Laying}

The average eggs weight for the chicken using the MMD diet was significantly higher $(\mathrm{p}<0.0001)$ than the other two diets from the $1^{\text {st }}$ to the $4^{\text {th }}$ week (Table $5)$. The average weight of the eggs for the CMD diet was homogeneous between the $1^{\text {st }}$ and $2^{\text {nd }}$ week and between the $3^{\text {rd }}$ and $4^{\text {th }}$ week $(\mathrm{p}>0.05)$. The average weights of the last 2 weeks were significantly higher than those of the first 2 weeks ( $\mathrm{p}$ 0.0003). The average weights of ACD eggs were homogeneous ( $\mathrm{p}>$ 0.0001 ) between the first 2 weeks and significantly lower than those of the last 2 weeks $(p<0.0001)$. Still in the same diet, the average weight of eggs in the last week was significantly higher than in the third week $(\mathrm{p}<0.0001)$.

\subsection{Weight, Density and Volume of Eggs According to Diets}

The results in Table 6 show that heaviest weights and densest eggs were recorded in the ACD diet. The largest egg was recorded in the MMD diet followed

Table 5. Weekly hen laying rate between rations.

\begin{tabular}{ccccc}
\hline \multirow{2}{*}{ Rations } & \multicolumn{4}{c}{ Observation periods } \\
\cline { 2 - 5 } & Week 1 & Week 2 & Week 3 & Week 4 \\
\hline CMD & $54.184^{\mathrm{b}}$ & $65.077^{\mathrm{b}}$ & $67.295^{\mathrm{c}}$ & $68.968^{\mathrm{b}}$ \\
ACD & $40.272^{\mathrm{b}}$ & $41.486^{\mathrm{a}}$ & $53.379^{\mathrm{b}}$ & $62.009^{\mathrm{b}}$ \\
MMD & $7.653^{\star}$ & $48.908^{\mathrm{a}}$ & $31.292^{\mathrm{a}}$ & $40.903^{\mathrm{a}}$ \\
Pr P F & 0.000 & 0.000 & 0.000 & 0.000 \\
Significance & Yes & Yes & Yes & Yes \\
\hline
\end{tabular}

${ }^{\star}$ Average of one day. MMD = Mango maize diet; $\mathrm{CMD}=$ Control maize diet; $\mathrm{ACD}=$ Absolute control diet. 
by the CMD diet. The largest weights and volumes were recorded in the MMD diet. The least heavy and least bulky egg was recorded in the CMD diet. The average weight and the average density of the eggs were significantly homogeneous among all the diets $(\mathrm{p}>0.05)$. The average egg volume of the MMD diet (40 \pm $\left.2.73 \mathrm{~cm}^{3}\right)$ was significantly greater $(\mathrm{p}<0.05)$ than of the CMD and ACD diets both homogeneous $(\mathrm{p}>0.05)$ (Table 7).

\section{Discussion}

\subsection{Effects of the Diet on the Growth Performance of the Growing Layers}

At the end of the experiment, the average weight reached by the growing layers between 16 and 17 weeks old of the corn control diet (CMD) and the absolute control diet (ACD) were similar as compared with those recommended by [2].

Table 6. Descriptive statistics of egg weight, density and volume.

\begin{tabular}{cccccc}
\hline Parameters & Diets & Mean & SD & Minimum & Maximum \\
\hline \multirow{2}{*}{ Weight $(\mathrm{g})$} & MMD & 47.55 & 3.885 & 35 & 54 \\
& CMD & 47.26 & 4.007 & 30 & 56 \\
\hline ACD & 47.05 & 4.247 & 38 & 67 \\
\hline Mensity $\left(\mathrm{g} / \mathrm{m}^{3}\right)$ & CMD & 1.11 & 0.28 & 0 & 1.37 \\
& ACD & 1.14 & 0.29 & 0 & 1.91 \\
\hline Volume $\left(\mathrm{cm}^{3}\right)$ & MMD & 1.15 & 0.29 & 0 & 1.93 \\
\hline & CMD & 39.44 & 2.73 & 33.25 & 48.03 \\
& ACD & 39.48 & 4.03 & 23.96 & 51.31 \\
\hline
\end{tabular}

$\mathrm{MMD}=$ Mango maize diet $\mathrm{CMD}=$ Control maize diet $\mathrm{ACD}=$ Absolute control diet.

Table 7. Weekly weight changes of eggs per ration.

\begin{tabular}{ccccc}
\hline Number of Weeks & & MMD & CMD & ACD \\
\hline 1 & $\mathrm{~N}$ & 14 & 15 & 11 \\
& Weight $(\mathrm{g})$ & $41.07 \pm 3.79^{\mathrm{a}}$ & $44.20 \pm 3.14^{\mathrm{a}}$ & $42.26 \pm 2.80^{\mathrm{a}}$ \\
\hline 2 & $\mathrm{~N}$ & 25 & 54 & 37 \\
\hline 3 & Weight (g) & $47.40 \pm 3.35^{\mathrm{b}}$ & $45.7 \pm 3.52^{\mathrm{a}}$ & $44.19 \pm 3.38^{\mathrm{a}}$ \\
\hline & $\mathrm{N}$ & 57 & 115 & 90 \\
\hline & Weight (g) & $48.05 \pm 3.18^{\mathrm{bc}}$ & $47.16 \pm 4.23^{\mathrm{b}}$ & $47.16 \pm 4.21^{\mathrm{b}}$ \\
\hline & $\mathrm{N}$ & 38 & 173 & 144 \\
& Weight (g) & $49.29 \pm 2.69^{\mathrm{c}}$ & $48.10 \pm 3.79^{\mathrm{b}}$ & $48.7 \pm 4.03^{\mathrm{c}}$ \\
\hline Signification & $\mathrm{R}^{2}$ & 0.283 & 0.103 & 0.230 \\
& $\mathrm{~F}$ & 16.439 & 4.796 & 12.449
\end{tabular}

$\mathrm{MMD}=$ Mango maize diet; $\mathrm{CMD}=$ Control maize diet; $\mathrm{ACD}=$ Absolute control diet. 
They were located between $1300 \mathrm{~g}$ (16 ${ }^{\text {th }}$ week) and $1400 \mathrm{~g}$ ( $17^{\text {th }}$ week), be it in average $1350 \mathrm{~g} / \mathrm{subject}$. The average weight reached by the subjects of the experimental mango diet (MMD) (1265.6 g), which is less efficient than those of the diets, agrees respectively with the recommendations of $1250 \mathrm{~g}$ for Isa Brown Hy-Line W-36 [15] and $1230 \mathrm{~g}$ for Hy-Line CV-22 strains at the $17^{\text {th }}$ week old [16]. These weight levels reached are the logical result of the ADG of the experimental diet, which was lower than those of the control diets. The average of the ADG of MMD diet $(9.176 \pm 1.633 \mathrm{~g})$ is similar to that $(9.0 \pm 7.0 \mathrm{~g})$ reported by [17] for a diet incorporating corn variety SR21 in Burkina Faso. However, it is lower than the ADG of the diets incorporating 2\% of Moringa (12.45 g) and 2\% of the pulp of Nere (10.78 g) as recorded by [1]. This low weight performance is due to the high dilution of energy by the fibers revealed through the results of the analyses of the chemical composition of the MMD diet. Indeed, the experimental diet concentrated at the end more fibers (CB, NDF, ADF) and 2 and 3 times of more lignin which is known to be indigestible than in CMD and ACD. With the monogastric species, in fact, the high levels of dietary fiber reduce the digestibility of diets and increase the feed intake. This kind of result has also been reported for mango wastes by [11]. This low performance of the MMD diet caused by the low availability of energy is not bad. In the framework of the preparation of the growing layers to laying, it is recommended to dilute the growing layer's diet by adding fibers generally present in some cereals by-products and in some oleaginous grains (all types of bran, Lucerne...) [18]. The author précised that high content of $\mathrm{CB}$ allows not only a good development of the digestive tract but also the widening of the pelvis for a lasting laying. The raw fibers which are not digestible or are a little bit digestible induce from what is called the training effect during the breeding stage and has a positive impact feathers pecking by the growing layers that leads to cannibalism. Indeed, the fact that the animals eat their feathers could be due to a strong desire of fibers which are not enough in the diet. This situation favors pecking among them [18]. In addition, there has been evidence of a relative increase in the size of the digestive tract organs associated with an increase in the fiber content in the growing layer feeding [19]. As a result of all said above, mango feed can be substituted by both maize for a rate of $37.65 \%$ and bran for $9.5 \%$ in diets of growing layers in preparation to laying. These rates are the consequences of the difference between the incorporation rate of mango and the incorporation rate of corn + bran in the MMD diet. It could be recommended in the preparation of the growing layers' ration because of its high content in fibers. It should be necessary to adjust the diets in order to take into account their biological values stemming from the analyses, especially as the results are variable when fruit wastes are used in the diet following the preparations [9].

\subsection{Effects of Ration on the Weight, the Shape, the Volume and the Density of Eggs}

It was brought out that the weight and the density of the eggs were not signifi- 
cantly influenced by adding mango in the rations of the laying hens. However, it is noted that in absolute value, the weight of the eggs of the MMD diet (47.55 \pm $3.89 \mathrm{~g})$ was higher than those in CMD $(47.26 \pm 4.01 \mathrm{~g})$ and ACD diets $(47.05 \pm$ $4.25 \mathrm{~g})$. Under similar environmental conditions as in Cote-d'Ivoire, the weight of the eggs of the MMD diet was very close and well-controlled by average weights between $46.54 \pm 0.44 \mathrm{~g}$ and $48.72 \pm 0.41 \mathrm{~g}$ reported by [20] [18] for the first month of laying of Isa Brown hens fed with maize. This proves that mango feed can replace corn in the ration. Similar results are reported in Benin by [21] for two experimental corn diets in which $5 \%$ and $10 \%$ of dried cassava leaves were incorporated. However, the weight of the eggs reported by these authors of more than $50 \mathrm{~g}$ was higher by 3 points for each of the CMD and ACD control diets and by 2 points for the MMD mango diet. The average egg volume of the MMD diet was significantly higher by 0.7 than CMD diet and 0.96 points than the ACD one. After measuring all the eggs were sold together. Experimental eggs were more preferred than those of the basic production unit because of their volume that attracts customers. The sale of eggs is the only objective of the promoter both on the station and in the laying hens' production units in Bobo-Dioulasso and elsewhere. In addition, for the customer the only visible parameter that can influence his choice is that of the size unlike the density and the weight which are hardly perceptible parameters. Indeed, eggs are not sold by weight or after the appreciation of its content (density). All this confirms the need to prepare the growing layers well for laying, ensuring among other things the adequacy of rations that can promote greater food consumption and good conformation of the pelvis. The dilution of the ration by adding food fibers is recommended in feeding growing layers when they are in preparation to laying; mango waste constitute an opportunity to make animals feed more available, especially for the laying hens and at the same time to favor an efficient preparation to laying.

\section{Conclusion}

Incorporation of mango waste in the laying hen diet increased the voluntary consumption of growing layers and resulted in larger eggs in the first month of laying compared to control diets. Mango waste is, therefore, an alternative for greater availability of animals' feed, particularly for laying hens. The slow growth due to the dilution of the ration by fibrous feeds like mango waste is a beneficial practice for the preparation of growing layers to laying, in this case for getting larger eggs in a lasting laying. There is a need to continue investigations by setting up trials covering both the growth period and the entire laying phase. The fact of the high incorporation of more than 50\% of mango waste in the MMD diet in substitution to maize grain and bran constitutes an opportunity to reduce the competition, in the use of cereals including maize, between humans and animals. It promotes the valorization of production and/or processing by-products such as mango waste. Further work following this exploratory study is needed to better refine the recommendations for the use of mango waste in the diet of laying hens. 


\section{Conflicts of Interest}

The authors declare no conflicts of interest regarding the publication of this paper.

\section{References}

[1] Yaro, D. (2011) Effet de la poudre de feuille de Moringa oleifera et de pulpe de fruit de Parkia biglobosa sur les performances de ponte des poules pondeuses. Mémoire d'Ingénieur de conception en vulgarisation agricole. Université Polytechnique de Bobo-Dioulasso, Burkina Faso, 50 p.

http://www.beep.ird.fr/collect/upb/index/assoc/IDR-2011-YAR-EFF/IDR-2011-YA R-EFF.pdf

[2] Dayon, J.F. and Arbelot, B. (1997) Guide d'élevage de volailles au Sénégal. 119 p. https://www.dphu.org/uploads/attachements/books/books_886_0.pdf

[3] Nau, F., Nys, Y., Yamakawa, Y. and Réhault-Godbert, S. (2010) Intérêt nutritionnel de l'œuf en alimentation humaine. INRA Productions Animales, 23, 225-236. https://www6.inra.fr/productions-animales_eng/content/download/5738/80971/ver sion/1/file/Prod_Anim_2010_23_2_12.pdf

[4] Kondombo, S.R., Kwakkel, R.P., Nianogo, A.J. and Singerland, M. (2003) Effects of Local Feedstuff Supplementation on Zootechnic Performances and Nutritional Status of Village Chickens during the End of the Rainy Season in Burkina Faso. Revue d’élevage et de médecine vétérinaire des pays tropicaux, 56, 199-204.

https://www.researchgate.net/profile/Aime_Nianogo/publication/40124758_Effects _of_Local_Feedstuff_Supplementation_on_Zootechnic_Performances_and_Nutriti onal_Status_of_Village_Chickens_during_the_End_of_the_Rainy_Season_in_Burki na_Faso/links/5527bf080cf29b22c9b93e65.pdf https://doi.org/10.19182/remvt.9865

[5] Pousga, S., Boly, H., Lindderberg, J.E. and Ogle, B. (2007) Evaluation of Traditional Sorghum (Sorghum bicolor), Beer Residues, Shea Nut (Vitellaria paradoxa) Cake and Cotton Seed (Gossypum spp) Cake for Poultry in Burkina Faso: Availability and Amino Acid Digestibility. International Journal of Poultry Science, 6, 666-672. http://docsdrive.com/pdfs/ansinet/ijps/2007/666-672.pdf https://doi.org/10.3923/ijps.2007.666.672

[6] Palo, P.E., Yamoégo, V.M.C. and Yanogo, A.J. (1991) Observations préliminaires sur l'utilisation des graines de Parkia biglibosa (Jacq.) Benth. (Néré) pour l'alimentation des pondeuses et des poulets de chair au Burkina Faso. Revue délevage et de médecine vétérinaire des pays tropicaux, 44, 179-184.

http://revues.cirad.fr/index.php/REMVT/article/view/9196

[7] Hien, O.C., Salissou, I., Diarra, B., Sanon, P.P. and Handcock, J.D. (2011) Effets comparés de rations à base des variétés de maïs ESPOIR et de maïs SR21 sur la productivité du poulet de chair de souche cobb-500. International Journal of Biological and Chemical Sciences, 12, 1557-1570.

https://www.ajol.info/index.php/ijbcs/article/view/180992

https://doi.org/10.4314/ijbcs.v12i4.4

[8] Dahouda, M., Toléra, S.S., Senou, M., Youssao, A.K.F. and IIambuckers, A. (2009) Les ressources alimentaires non-conventionnelles utilisables pour la production aviaire en Afrique: Valeurs nutritives et contraintes. Annales de médecine vétérinaire, 153, 5-21.

https://orbi.uliege.be/bitstream/2268/28912/1/Les\%20ressources\%20alimentaires\%2 0non-conventionnelles.pdf 
[9] Kiendrébéogo, T., Mopate, L.Y., Ido, G. and Kaboré-Zoungrana, C.-Y. (2013) Procédés de production d'aliments non conventionnels pour porcs à base de déchets de mangues et détermination de leurs valeurs alimentaires au Burkina Faso. Journal of Applied Biosciences, 67, 5261-5270.

https://www.ajol.info/index.php/jab/article/view/95047 https://doi.org/10.4314/jab.v67i0.95047

[10] Guinko, S. (1984) Végétation de Haute Volta. Thèse de Doctorat d'état. Université de Bordeaux III (France), Bordeaux, 145 p.

[11] Kiendrébéogo, T., Mopaté, L.Y. and Kaboré-Zoungrana, C.-Y. (2018) Effets de rations à base de déchets de mangue sur les performances pondérales et la qualité de la carcasse de porcs Korhogo en croissance au Burkina Faso. Journal of Applied Biosciences, 129, 13039-13049. https://www.ajol.info/index.php/jab/article/view/181679 https://doi.org/10.4314/jab.v129i1.7

[12] Hoyt, D.F. (1979) Practical Methods of Estimating Volume and Fresh Weight of Bird Eggs. The Auk, 96, 73-77. https://sora.unm.edu/sites/default/files/journals/auk/v096n01/p0073-p0077.pdf

[13] Augion, S. (2007) Eléments sur la biologie de l'CEdicnème criard en Agroécosystèmes intensif et perspectives de conservation. Ecologie, University Pierre et Marie Curie, Paris, $44 \mathrm{p}$.

[14] Sauveur, B. (1988) Reproduction des volailles et production d'œufs. Ed. Institut Nati. INRA, Paris, 455 p. https://sacomlithefer.firebaseapp.com/2853409619.pdf

[15] ISA 2009-10 (2009) Guide d'élevage général des pondeuses commerciales Isa brown. $41 \mathrm{p}$.

https://sansdents.com/wp-content/uploads/2019/02/ISA-BROWN-GUIDE-D\%E2\% 80\%99\%C3\%89L\%C3\%89VAGE-GENERAL-DES-PONDEUSES-COMMERCIALE S.pdf

[16] Hy-Line (2018) Pondeuses commerciales Hy-line Brown, Guide de gestion. 30 p. https://www.hyline.com/userdocs/pages/BRN_COM_FRN.pdf

[17] Coulibaly, Y. (2014) Effects de la variété du maïs Espoir sur la productivité des poules pondeuses. Mémoire de master en production et industrie animales. UPB/IDR, $70 \mathrm{p}$. http://www.beep.ird.fr/collect/upb/index/assoc/IDR-2014-COU-EFF/IDR-2014-CO U-EFF.pdf

[18] Robert, H., Galik, B., Biro, D., Rolinec, M., Sinko, M., Jurasek, M., Majlat, M. and Harpasova, H. (2014) The Effect of Pumpkin and Flaxseed Oils on Selected Parameters of Laying Hen's Performance. Acta Fytotechnica et Zootechnica, 17, 96-99. http://acta.fapz.uniag.sk/journal/index.php/on_line/article/view/112/pdf_16 https://doi.org/10.15414/afz.2014.17.03.96-99

[19] Beghoul, S. (2015) Effets de l'utilisation des céréales et des protéagineux autres que le maïs et le soja dans l'alimentation du poulet de chair. $177 \mathrm{p}$.

http://archives.umc.edu.dz/bitstream/handle/123456789/130682/BEG6667.pdf?sequ ence $=1 \&$ isAllowed $=\mathrm{y}$

[20] Brou, G.K.G., Houndonougbo, F.M., Abo, A.B., Mensah, G.A. and Fantodji, A. (2012) Effet de la variation temporelle de la température ambiante journalière sur le poids des œufs de poules pondeuses ISA Brown en Côte-d'Ivoire. International Journal of Biological and Chemical Sciences, 6, 2158-2169.

https://www.ajol.info/index.php/ijbcs/article/view/85272/75210 https://doi.org/10.4314/ijbcs.v6i5.23

[21] Houndonougbo, M.F., Chrysostome, C. and Houndonougbo, V.P. (2012) Performances bioéconomiques des poulettes alimentées avec des rations à base de feuilles 
séchées de manioc (Manihot esculenta). International Journal of Biological and Chemical Sciences, 6, 670-676.

https://pdfs.semanticscholar.org/8a1a/581496dd19da15122024a4d82e620d0bc064.p $\underline{\mathrm{df} ? \text { ga }=2.265188751 .1492628228 .1570750133-472848667.1570750133}$

https://doi.org/10.4314/ijbcs.v6i2.11 